\title{
MARKETING CULTURAL TOURISM IN A DEVELOPING COUNTRY SETTING: THE CASE OF MURSHIDABAD, WEST BENGAL, INDIA
}

\author{
RUPA SINHA*† AND STEPHEN PRATT: \\ *Institute of Management Studies, Maulana Abul Kalam Azad University of Technology, Kolkata, India \\ $†$ School of Hospitality and Tourism Studies, SRM University, Sikkim, India \\ $\$$ School of Tourism \& Hospitality Management, Faculty of Business \& Economics, The University of the \\ South Pacific, Suva, Fiji
}

\begin{abstract}
Many potential destinations are rich in cultural resources. As cultural tourism becomes increasingly important for communities to showcase their cultural capital, it is vital to assess how cultural tourists can be better understood and serviced through planning and marketing to attract more international visitors. The marketing funnel process can help policymakers understand the critical components of tourists' visiting behavior. The process conceptualizes the process of how a consumer purchases a product or service from awareness through to purchase. We augment this marketing funnel process by also noting the importance of postconsumption evaluation: the likelihood to recommend. Cultural heritage tourism is an important feature of India's tourism. Murshidabad, a district of West Bengal, India, situated on the bank of Bhagirathi River, is $220 \mathrm{~km}$ away from the State capital, Kolkata. Murshidabad has a large number of cultural resources, both tangible and intangible. The study explores the cultural resources and their potential availability in Murshidabad. This will determine the scope of cultural heritage tourism development. This research assesses tourists' awareness, visitation, and likelihood to recommend cultural heritage resources in Murshidabad. It also assesses residents' perceptions towards cultural heritage tourism development as well as the community's participation level in cultural tourism development. This research uses a quantitative method to sample both tourists and the local community. The findings reveal strong support for cultural tourism development among the local community and high willingness to recommend many cultural attractions, although promotion and awareness of some attractions can be improved.
\end{abstract}

Key words: Cultural tourism; India; Marketing funnel; Product development

\section{Introduction}

Tourism can be a mechanism to build mutual understanding, enriching varied cultures and lifestyles between two countries by bringing diverse people face to face (Nyaupane et al., 2008). Tourism has been recognized as a major contributor to international goodwill and a means of developing social justice and promoting friendship (Askjellerud, 2003). Tourism development affects the social, 
cultural, and environmental elements within a destination (Nunkoo \& Ramkissoon, 2010). Sociocultural impacts are concerned with how tourism is contributing to changes in value systems, individual behavior, family relationships, collective lifestyles, moral conduct, creative expressions, traditional ceremonies, and community organization (Deery et al., 2012). According to Tylor (1871), "culture" is that complex whole that includes knowledge, beliefs, arts, morals, laws, customs, and any other compatibilities and habits acquired by the society. Cultural tourism can bring positive impacts through the understanding of history and culture (Girard \& Nijkamp, 2009). A better understanding of heritage may foster memorable experiences and greater understanding between different communities (Seyfi et al., 2020). In the wake of globalization, many destinations and communities have started to rethink their policies and strategies for preserving and strengthening their culture (Tolkach $\&$ Pratt, 2019). At the same time, these communities have realized the importance of cultural tourism and its potential positive impacts (Zieba, 2016).

As highlighted by United Nations World Tourism Organization (UNWTO), there are two perspectives regarding the definition of cultural tourism (UNWTO, 2001). The broad approach sees cultural tourism as movements of all persons being included in the definition because they satisfy the human need for diversity, tending to raise the cultural level of the individual and giving rise to new knowledge, experience, and encounters (Noonan \& Rizzo, 2017). In contrast, a more narrow definition of cultural tourism is movements of persons for essentially cultural motivations such as study tours, performing arts and cultural tours, travel to festivals and other cultural events, visits to sites and monuments ( $\mathrm{Su} \& \mathrm{Cai}$, 2019). For this research, we follow the narrow definition, as we seek to explore cultural tourism product development and management. UNWTO predicted cultural tourism will be one of the five key tourism market segments in the future (UNWTO, 1999).

International Council on Monuments and Sites (ICOMOS, 1990) further defined cultural tourism as activities that enable people to experience the different ways of life of other people, thereby gaining a first-hand understanding of their customs, traditions, the physical environment, their ideas, and those places of architectural, historic, archeological, or other cultural significance that remain from earlier times (Jovicic, 2016). As with other forms of tourism, cultural tourism development can have both favorable and unfavorable consequences for host communities. Not only does it generate benefits, it also imposes costs (Jafari, 2001). By evaluating these benefits and costs, host communities can develop their cultural tourism products and better meet the needs of tourists (Mubanga \& Umar, 2016).

An understanding of residents' attitudes towards tourism development and their determinants is essential to achieve sociocultural development in a host region (Pechlaner et al., 2015). So for the development of cultural tourism in a certain destination, local people's support and involvement are important (Canalejo et al., 2015). Likewise, from a demand perspective, tourists are seeking a more flexible, diversified, and customized experience. They prefer to mix with the local population, enjoy nature and adventure, travel in diversified interest groups, and often opt for exploration and heightened experiences (Mowforth \& Munt, 2015). As such, destinations need to cater to these new demands and satisfy tourists' experiential needs.

This research compares and contrasts a local community's awareness and attitudes toward cultural tourism and tourists' awareness and attitudes of the same. The overall purpose of the article is to understand the marketing potential for cultural tourism in a developing country. Specifically, the objectives of the research are 1) to assess tourists' awareness, visitation, and likelihood to recommend cultural heritage resources in the study area; 2) to determine the local community's perceptions towards cultural tourism; 3) to assess the level of participation by the local community in cultural tourism development; and 4) to provide recommendations from the local community on how to further develop cultural tourism. We achieve these objectives through a quantitative survey conducted among both tourists and the local community. The study findings will be useful to destination marketers and tourism marketing professionals in developing countries who seek to develop and promote their cultural tourism assets.

\section{Literature Review}

\section{Cultural Tourism Motivations and Typologies}

Given that culture is one of the primary motivations for tourism and that cultural attractions are 
one of the most important features of a community, it is not surprising that there has been a lot of literature on cultural tourism. Richards (2018) provided a recent review of cultural tourism that identifies the major trends and research areas over the past decade. Emerging areas are cultural consumption, cultural motivations, heritage conservation, cultural tourism economics, anthropology, and the relationship with the creative economy (Richards, 2018). McKercher and Du Cros (2002) identified four different types of cultural tourism definitions: tourism-derived definitions, motivational definitions, experiential definitions, and operational definitions. Tourism-derived definitions focus on cultural tourism from the perspective of the tourism industry. The motivational definitions usually begin with the tourists themselves and their reasons for travel to a cultural destination. The experiential definition focuses on the nature of the cultural tourism experience (Jovicic, 2016). The operational definition concentrates on identifying cultural tourists to understand the scale or scope of cultural tourism activity.

Cultural tourism is more than just museums, monuments, and other built environments (Noonan \& Rizzo, 2017). It involves both the tangible and intangible. Csapo (2012) outlined seven types of cultural tourism: Heritage Tourism; Cultural thematic routes; Cultural city tourism, cultural tours; Traditions, ethnic tourism; Events \& festival tourism; Religious tourism, pilgrimage routes; and Creative culture, creative tourism. Heritage tourism represents both natural and cultural heritage, connected to nature-based resources. In contrast, cultural heritage includes built heritage, architectural sites, world heritage sites, national and historical memorials. Literature, folks, art, etc., comes under nonmaterial attributes. Redondo-Carretero et al. (2017) provided an insightful example of language tourists' motivations and perceptions of the destination while studying Spanish in Valladolid, Spain. Cultural thematic routes represent a wide range of themes, which include artistic, spiritual, gastronomic, architectural, linguistic, vernacular, and minority. Cultural city tourism and cultural tours can be grouped into three broad categories, which include "classic" city tourism, involving sightseeing, cultural capital, or resources of that particular destination and "cities as creative spaces for cultural tourism." van Loon and Rouwendal (2017) provided a case study of Amsterdam where expenditure patterns of urban tourists visiting for different cultural tourism purposes demonstrate the substantial and widespread expenditures on a range of cultural tourism experiences and products. Traditions and ethnic tourism include a local culture's traditions and ethnic diversity. Events and festivals tourism represent cultural festivals and events such as music festivals and fine arts festivals. Religious tourism and pilgrimage routes refer to visiting religious sites with religious motivations (Jimura, 2011). Creative culture and creative tourism include traditional culture and artistic activity (performing arts, visual arts, cultural heritage, and literature) as well as cultural industries that represent multimedia, cinema, audiovisual, and phonographic productions, crafts, and design (see, e.g., Fahmi et al., 2017; Wattanacharoensil \& Schuckert, 2016).

Cultural tourists can be segmented by the depth of their experience (McKercher \& Du Cros, 2002). Other literature has classified tourists as being culturally interested, culturally motivated, or culturally inspired (Economist Intelligence Unit, 1993). Culturally interested tourists are those who are moderately interested in culture and visit cultural attractions as part of their holidays. Culturally motivated tourists are those who have enough motivation in culture and visit cultural attractions as a part of their holiday but who are not choosing their destination based on specific cultural experiences. Culturally inspired tourists are those who are inspired by culture and travel long distances to gain some cultural experience. The main goal of their holiday is to learn about different cultures (Nyaupane \& Andereck, 2014).

\section{Community Support for Cultural Tourism}

As with other forms of tourism, the support and development of cultural tourism among the local community will depend on the perceived benefits and costs derived from tourism (Ap, 1990). Residents who perceive positive tourism impacts are more willing to support future tourism development policies (Mason \& Cheyne, 2000). Alternatively, residents who perceive the negative impacts of tourism are less willing to support any further tourism 
development (Lankford et al., 1994). Tourism is an industry that uses the host community as a resource and sells the host community's cultures as a product (Murphy, 1981). In the process, tourism affects the lives of all in the community, whether involved directly in tourism or not. So the community itself is a product, as the development depends on the community's attitude as well as involvement. Residents' attitudes toward tourism may vary in space, depending on the location of communities, and residents exhibit a wide range of attitudes towards tourism development (Faulkner \& Tideswell, 1997). In general, there is evidence that cultural tourism in rural areas in developing countries is supported by the local community as they recognize the economic, cultural, and social benefits provided by tourism (Türker \& Öztürk, 2013). Residents also acknowledge that tourism development creates trade-offs so the development may come at the cost of environmental degradation and traffic congestion (Deery et al., 2012). Despite this, in general, residents are in favor of tourism development (Andereck et al., 2005). Others have acknowledged that without community involvement, no tourism development is possible (Wang \& Pfister, 2008). So, for the development of cultural tourism, residents' attitudes towards development are important.

Residents' support for cultural tourism needs to be facilitated and shaped by the government (Lehman et al., 2017). Policymakers are starting to see the multifaceted benefits of cultural tourism strategies that can sustain intangible culture, provide economic opportunities, and livelihoods and preserve tangible cultural heritage (Airey \& Ruhanen, 2014). It is an opportunity to mitigate against unregulated growth (Russo, 2002) and it is often prudently linked to regional government policy development (Markusen \& Gadwa, 2010). Loulanski and Loulanski (2011) highlight the importance of local community support in cultural heritage, while Jimura (2011) noted how the designation of a world heritage status site can improve the local communities' attitudes towards conservation of the cultural environment. Cultural tourism can also improve the city's image and strengthen community pride, as in the case of Gwangju, South Korea (Shin, 2010). The interpretation to understand cultural symbolism and significance is embedded in both cultural and tourism institutions when applied to cultural tourism so that there is a mutual dependence between both sectors (Su \& Cai, 2019).

\section{Cultural Tourism Development}

Several authors have noted the economic contribution of cultural tourism (Henderson, 2011). For example, Silberberg (1995) highlighted that heritage sites and museums are ways to increase visitation to a region so that the destination can generate economic benefits and employment among the local community. In doing so, the public sector has a responsibility to look after its resources so that the visitor experience is maintained to a high level (Ababneh, 2015). Therefore, it is imperative to have prudent management and properly trained tour guides. As the sheer volume of tourists is predicted to rise, the growth in visitor numbers may damage existing cultural resources. With the commodification of culture, cultural resources and heritage sites may becoming extinct (Suntikul et al., 2016). On other hand, a rise in niche cultural tourism markets will encourage the need for training of cultural heritage specialist guides. The development of such niche markets of cultural tourism has given birth to culturally sensitive and education seeking tourists. For any cultural tourism attraction to be successful it need to be able to generate economic, environmental, and sociocultural benefits to a community.

Given the growing importance of cultural tourism, the potential benefits cultural tourism can provide, and the need for local community support to ensure the benefits of cultural tourism are maximized and flow to the local community, this research contributes to the body of knowledge in this area. The context explored in Murshidabad, India is a useful case study as it has numerous cultural heritage attractions and is situated in a developing country, which is trying to maximize the benefits of tourism. The conceptual framework with which to understand this cultural tourism development is the marketing funnel, described below.

\section{Marketing Funnel}

Marketers have used the buying funnel, sales funnel, or marketing to conceptualize the process of how a consumer purchases a product or service (Jansen \& Schuster, 2011). The underlying theory 
of the marketing funnel is information processing theory (Bettman et al., 1998). Information processing theory proposes that consumer decision making comprises a five-stage process: problem recognition; information search; alternative evaluation and selection; outlet selection and purchase; and postpurchase processes (Sirakaya \& Woodside, 2005). Although different terminology has been used in the literature, the marketing funnel generally has the following stages: Awareness, Research, Decision, and Purchase. The marketing funnel has been commonly used in the marketing literature (Young et al., 2006) and more specifically in the tourism marketing literature (Camilleri, 2018).

The idea of the funnel arises because there is a sequence to the buyer decision process (Fig. 1). The model suggests that consumers (tourists) go through stages of cognition and action before they decide whether and what service (cultural tourism site) to purchase (visit) (Doshi et al., 2017). The marketing funnel, also known as the buying funnel or sales funnel, models how marketers can reach consumers (Jansen \& Schuster, 2011). Potential visitors progress through the different cognitive stages to get to the purchase/visit stage. The model aligns with broader concepts of decision making from the psychology discipline (Simon, 1977). The first step in the process is Awareness. The buyer/tourist has to be aware of the cultural tourist attraction before they can even consider it. The tourist has to have a conscious need to experience the cultural tourist attraction and a conscious desire to meet that need. This involves gathering information about potential sites and establishing whether they meet expectations (Woodside \& Lysonski, 1989). This awareness stage is often coupled with the second stage. The second stage, the Research stage, is an information-gathering stage. The potential cultural tourists need information on the available attractions

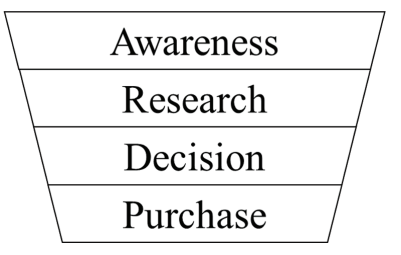

Figure 1. Marketing funnel. to determine whether that attraction can fulfill that need and desire. Cultural tourism suppliers want to move potential tourists through the purchasing funnel, to have the tourists visit the attraction. The decision stage involves the potential tourists developing a mental consideration set of the potential cultural tourist attractions they would like to attend with their limited time and financial resources. Here they enter the decision-making process among this consideration set. The purchase stage involves the potential cultural tourists deciding to purchase/visit (or not), given the comparisons across attraction attributes such as price, convenience, and quality of attraction. Consumers follow a funnel-like procedure of narrowing down choices among alternate attractions (Sirakaya \& Woodside, 2005) where the choice of attraction is the result of a sequential process of reducing the set of alternatives, from a large number of alternatives in the early stages to select few that are visited (Jiang et al., 2009).

Word of mouth is critically important nowadays and has become more important with the ubiquitous nature of social media (Cox et al., 2009; Mate et al., 2019). Hence, for this study we take an adapted Buying Funnel and include the Information Processing stage of Postpurchase processes to include the Recommendation stage. Hence, the conceptual framework we will follow can be seen in Figure 2. In this study, we capture the awareness of the different cultural attractions, as awareness is a precursor to visit. The awareness stage is often coupled with the research stage while the decision stage of the marketing funnel can be observed in terms of whether or not the tourist visited the cultural tourism attraction. This is why these stages are merged out in Figure 2. The survey instrument captures whether these cultural tourists have visited

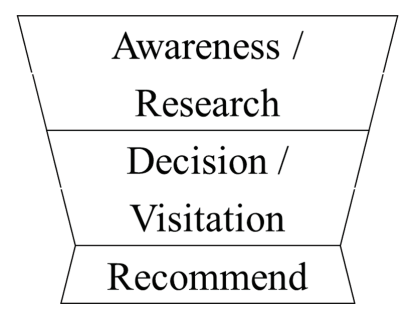

Figure 2. Adapted marketing funnel. 
any of the eight cultural attractions noted below. The "conversion" rate is the ratio of those who visited the attraction as a proportion of those who are aware of the attraction (Eq. 1). In other words, conversion expresses the proportion of those who visit the cultural tourist attractions are a subset of those who are aware of the cultural tourist attraction. This formula is a mathematical way to demonstrate the funnel process. For those who visited, we asked their likelihood of a recommendation.

$$
\text { Conversion }=\frac{\text { Visited }}{\text { Aware }}
$$

The Case of Murshidabad, West Bengal, India

The study site is Murshidabad, a district of West Bengal, India. In West Bengal, many destinations have rich cultural resources (Fig. 3). Among them,
Murshidabad, Land of Nawabs, is located beside the bank of the Bhagirathi River. This historic city has a colorful past. It was witness to British imperialism as well as being an early modern financial center in the land of Bengal during the 18th century. Silk was a major product of Murshidabad. The city was also a center of art and culture, including for ivory sculptors, Hindustani classical music, and the Murshidabad style of Mughal painting. Every year thousands of domestic as well as international tourists visit this historic city. As such, the development of cultural tourism with proper conservation of resources is important. The magnificent forts and palaces, architectures, museums, and the diversity of cultures and traditions have tremendous potential to attract tourists. As such, this research can inform policymakers.

Figure 4 shows a more detailed map of the cultural tourist attractions in Murshidabad. All of the eight cultural tourist attractions are situated

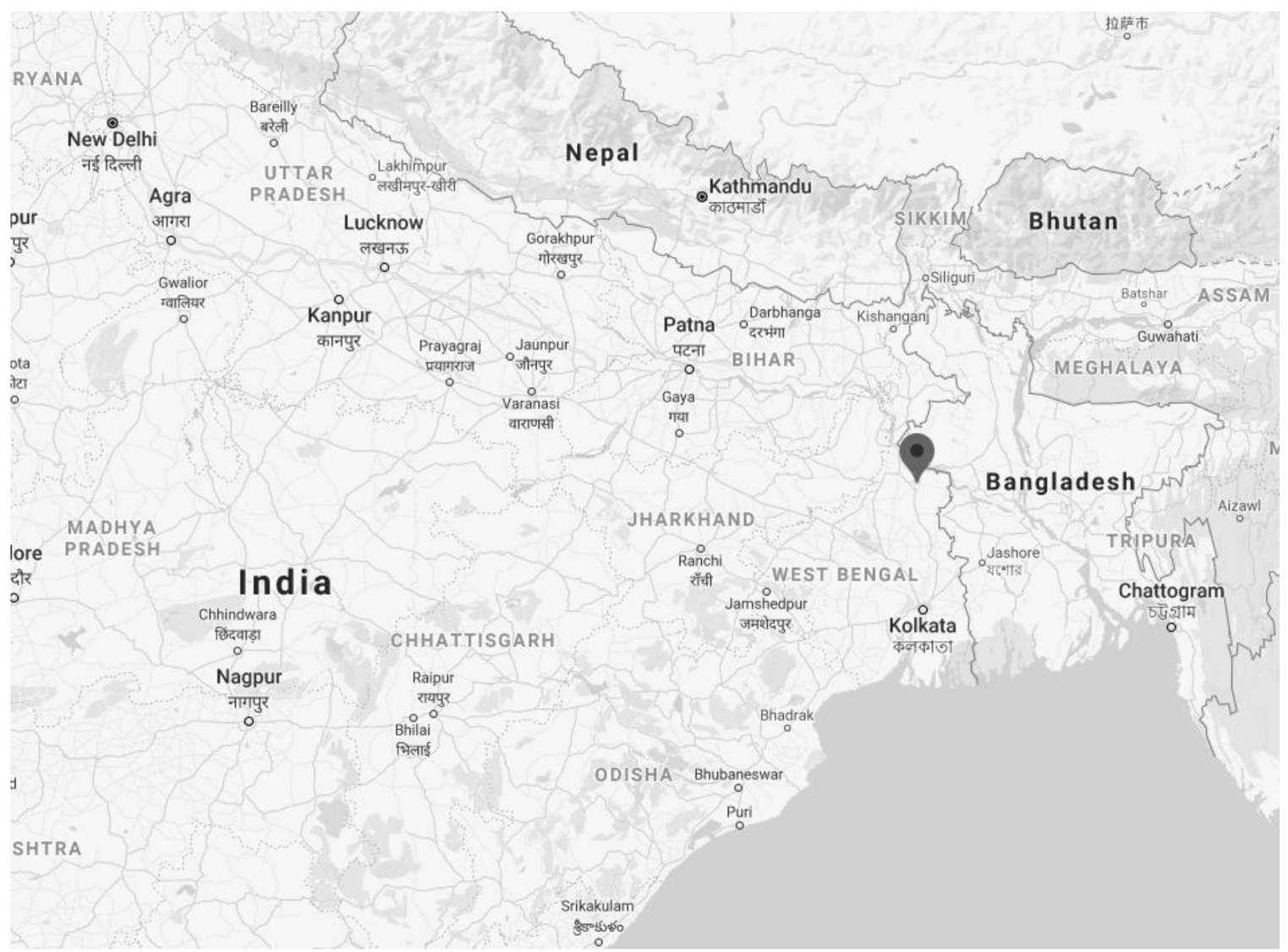

Figure 3. Location of Murshidabad. Source: Google maps. 


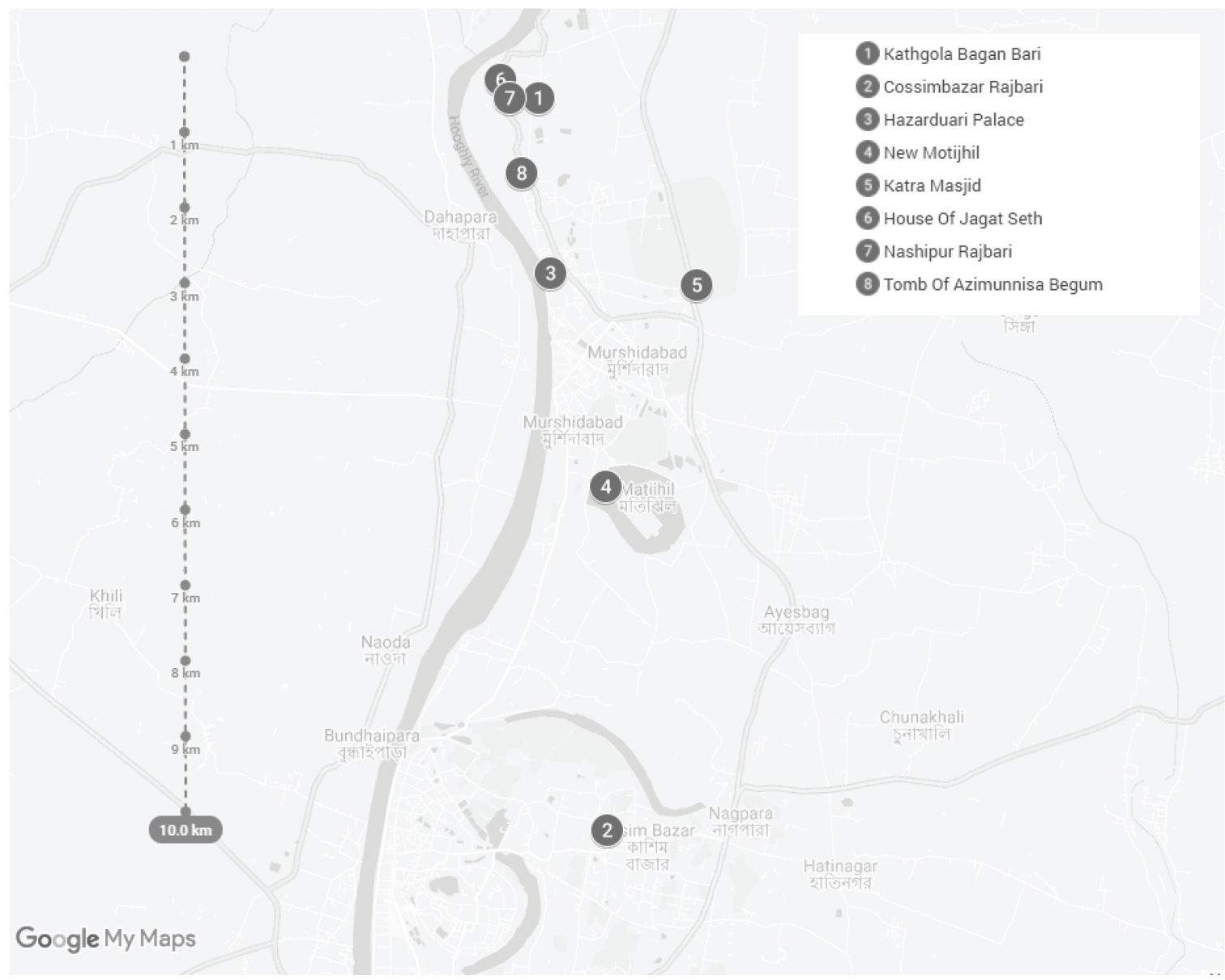

Figure 4. Murshidabad tourist attractions. Source: Google maps.

along the Bhagirathi River and cover a distance of around $10 \mathrm{~km}$. Kathgola Bagan is a palace complex originally built to entertain European and Muslim guests during trade visits. A large number of Hindu devotees visit for religious purposes. Cossimbazar Rajbari was a trading hub for silk and muslin and also a trading island in British colonial times. Hazarduari Palace is one of the most significant tourist attractions in Murshidabad. This palace was built by Duncan McLeod in 1837 for the Nawab Najim Human Jah. The palace has been converted into a museum and comprises a collection of nearly 3,000 artifacts including portraits of Nawab, swords used by Nawab, a collection of vintage cars, pieces of ivory, and relics. New Motijhil comprises a palace with a lake and reflects both Indian and British history. Motijhil later served as a residence for Lord Clive, Warren Hastings, and other British Lords (see Fig. 5). Katra Masjid is a well-maintained mosque built in 1724 by Murad Farash Khan. A wealthy money-lending family, the Jagat Seth family, were known as the "bankers of the world." Jagat Seth House is situated nearby Hazarduari Palace and has been converted to a museum, comprising of the personal effects of Jagat Seth and family members. The Nasipur Palace complex comprises Ram Chandra Temple, one of the largest temples in the district, and Laxmi Narayan Temple. The Tomb of Azimunnisa Begum was built in 1734. This is the graveyard and an old mosque of Azimunnisa Begum, who was the daughter of Murshid Quli Khan. Her grave is under the staircase like her father. 

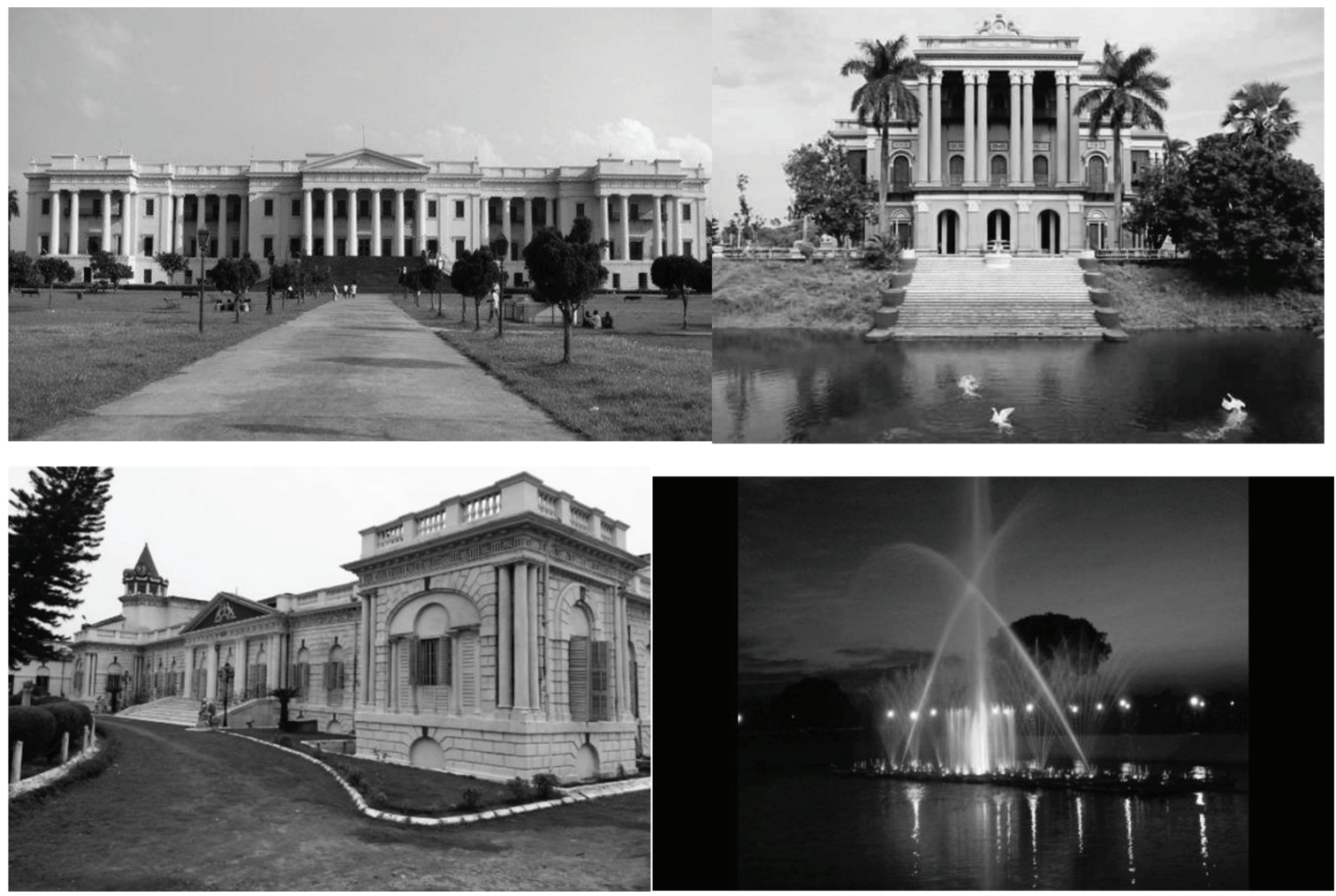

Figure 5. Murshidabad Cultural Attraction. Clockwise from top left: Hazarduari Palace, Kathgola Bagan, New Motijheel and Cossimbazar Rajbari.

\section{Methodology}

To address the research objectives, a quantitative study was deemed to be most suitable. For comparison, a survey was conducted with both tourists and the local community. The reason for two survey instruments relates to the research objectives where the first research objective seeks to determine tourists' awareness, visitation, and likelihood to recommend cultural heritage resources in the study area and the other research objectives seek to assess views from the local community. This enables the research to examine both tourism demand and tourism supply of cultural tourism development in Murshidabad. The data were collected across different seasons. It started in January 2017 and ended in March 2018.

\section{Tourist Questionnaire Design and Sample}

The tourist questionnaire comprised two main parts. The first part captured a standard set of demographic questions such as age, gender, the highest level of education, and occupation. The second part of the tourists' questionnaire captured travel information such as tourists' geographic origin, the purpose of the trip, length of stay, composition of the travel party, trip expenditure, and awareness, visitation, and recommendation as a must-see attraction for eight cultural tourist attractions in Murshidabad. Awareness and visitation were asked directly. For awareness, tourists were asked, "Please indicate which of the following places have you ever heard of." For visitation, tourists were asked, "Please indicate which of the following places have you ever visited." Tourists' recommendations were recorded on a 7-point Likert scale where 1 is not at all important and 7 is extremely important. Assessing stages in the marketing funnel in this tiered way is a relatively common way to capture the data (Colicev et al., 2019; Jansen \& Schuster, 2011; Söhnchen \& Albers, 2010). 
Purposeful sampling was undertaken for data collection from tourists. The lead researcher conducted face to face paper-based interviews in and around common locations of Murshidabad where potential tourists visited. No strict quotas were set but the researcher ensured she approached a mix of tourists in terms of the demographic characteristics. On approach, the researcher explained the purpose of the research, assured the potential respondents the researcher was not trying to sell the person anything, guaranteed their anonymity, and explained the respondent didn't have to answer any question they did not want to and could stop the survey at any time. The average time for completion was 7 min. The target sample size was $N=200$, which was deemed appropriate for a healthy level of statistical significance, given the time constraints and research budget. At the end of the data collection period, the final sample size was $N=176$ usable questionnaires for analysis. This resulted in a maximum sampling error of $\pm 7.4 \%$. The demographic profile of the tourists' sample can be seen in Table 1.

Table 1 shows that tourists to Murshidabad are diverse. Gender was almost split 50:50. There was a range of age groups sampled with almost a quarter of the sample less than 25 years old and another

Table 1

Tourists' Demographic Profile

\begin{tabular}{ll}
\hline & Frequency (\%) \\
\hline Gender & \\
Male & $89(50.6 \%)$ \\
Female & $87(49.4 \%)$ \\
Age & $42(23.9 \%)$ \\
Less than 25 years & $62(35.2 \%)$ \\
26-35 years & $31(17.6 \%)$ \\
36-45 years & $28(15.9 \%)$ \\
46-55 years & $13(7.4 \%)$ \\
Above 55 years & \\
Education level & $66(37.5 \%)$ \\
Higher school or below & $82(46.6 \%)$ \\
Graduate & $28(15.9 \%)$ \\
Postgraduate & \\
Occupation & $42(23.9 \%)$ \\
Self-employed & $32(18.2 \%)$ \\
Private sector (nontourism) & $24(13.6 \%)$ \\
Public sector & $16(9.1 \%)$ \\
Tourism \& hospitality & $20(11.4 \%)$ \\
Other & $42(23.9 \%)$ \\
Unemployed/student &
\end{tabular}

$35 \%$ between the ages of 25 and 34 years. There was a mix of education levels too, with $38 \%$ being high school graduates and a further $47 \%$ being university or college graduates. In terms of occupations, almost a quarter were self-employed and another quarter were students or unemployed. The remainder were a mix between the private and public sectors.

\section{Local Community Questionnaire Design and Sample}

The survey instrument for the local community consisted of three broad parts. The first part sought data on the respondents' demographic information. Questions in this section included the length of residency in Murshidabad, gender, age, marital status, level of education, family type (nuclear or extended), and occupation. The second section of the questionnaire asked the local community to name cultural resources tourists would be interested in seeing and visiting across several categories: places for local handicrafts; cultural/heritage destinations to visit; tangible cultural resources (folk dance, music, drama, festivals, and cuisines); and lesser-known destinations with cultural/historic importance. This section also included a battery of questions on the local community's perception of the scope for cultural tourism development in Murshidabad. Eleven statements were posed and respondents' were asked their level of agreement on a 5-point Likert scale where 1 is strongly disagree and 5 is strongly agree. Previous literature was adapted to create these statements that asked residents about their attitudes and perceptions of tourism (Andereck et al., 2005; Dragouni \& Fouseki, 2018; Sharma \& Dyer, 2009). A further five statements asking about community participation about cultural tourism were posed to respondents on the same Likert scale. The last section of the local community questionnaire asked questions about the level of participation by the local community in accommodation and transportation as well as recommendations from the local community on how to further develop cultural tourism.

A pilot survey was first undertaken among 44 respondents within Murshidabad's community. Several small changes were made in the wording to improve readability and comprehension. After the 
pilot study, the main study was conducted using a convenience sample among the local community. The first author contacted their friends, family, colleagues, and acquaintances in the first instance. Referrals were then suggested for additional respondents. The final usable sample size was $N=$ 210. This resulted in a maximum sampling error of $\pm 6.8 \%$. The average time for completion was 9 min. As with the tourist sample, an ethical protocol such as assured anonymity, the ability to cease the survey, and informed consent was obtained before the survey took place. The demographic profile of the local community is shown in Table 2 .

Almost half of the local community surveyed were born in Murshidabad and another $40 \%$ had lived there for 10 years or longer. Only $13.3 \%$ were residents for less than 10 years. More males were surveyed than females. The age breakdown was spread across the categories. Over half the

Table 2

Demographic Profile of Local Community

\begin{tabular}{lc}
\hline & Frequency (\%) \\
\hline Length of residency & \\
Less than 10 years & $28(13.3 \%)$ \\
Longer than 10 years & $83(39.5 \%)$ \\
Born in Murshidabad & $99(47.1 \%)$ \\
Gender & \\
Male & $141(67.1 \%)$ \\
Female & $69(32.9 \%)$ \\
Age & \\
Less than 25 years & $41(19.5 \%)$ \\
26-35 years & $69(32.9 \%)$ \\
36-45 years & $64(30.5 \%)$ \\
46-55 years & $21(10.0 \%)$ \\
Above 55 years & $15(7.1 \%)$ \\
Marital status & \\
Single & $92(43.8 \%)$ \\
Married & $117(55.7 \%)$ \\
Widowed & $1(0.5 \%)$ \\
Family type & \\
Nuclear & $141(67.2 \%)$ \\
Extended & $69(32.9 \%)$ \\
Education level & \\
High school or below & $47(22.4 \%)$ \\
Graduate & $114(54.3 \%)$ \\
Postgraduate & $49(23.3 \%)$ \\
Occupation & \\
Self-employed & $38(18.1 \% 0$ \\
Private sector (nontourism) & $31(14.8 \%)$ \\
Public sector & $40(19.0 \%)$ \\
Tourism \& hospitality & $50(23.8 \%)$ \\
Others & $22(10.5 \%)$ \\
Unemployed & $29(13.8 \%)$ \\
\hline & \\
& \\
\hline &
\end{tabular}

respondents were married and two thirds lived in a nuclear family. Over half of the respondents were university or college graduates. In terms of occupations, there was a mix with almost a quarter of the sample working in the private sector of the tourism and hospitality industries.

\section{Results}

\section{Tourists}

The trip profile of the tourists to Murshidabad shows that the large majority of visitors to the region were domestic tourists $(83.5 \%)$ from within West Bengal while there was a small proportion of local tourists and interstate tourists. Over half $(51.7 \%)$ of the tourists visited for general leisure purposes and over half $(55.7 \%)$ of the tourists were day-trippers. Another third (32.9\%) of tourists stayed overnight in Murshidabad for up to a week. Just under half $(45.5 \%)$ of the tourists were traveling with their family and almost a third (31.3\%) were traveling with friends (Table 3).

An assessment of tourists' awareness, visitation, and likelihood to recommend cultural heritage resources in Murshidabad is shown in Figure 6. There was a high awareness of four sites; Hazarduari Palace, Kathgola Bagan, Cossimbazar Rajbari, and New Motijheel. All tourists were

Table 3

Tourist Trip Profile

\begin{tabular}{lc}
\hline & Frequency (\%) \\
\hline Tourist origin & \\
Within town (Murshidabad) & $18(10.2 \%)$ \\
Within state (West Bengal) & $147(83.5 \%)$ \\
Interstate & $11(6.3 \%)$ \\
Purpose of trip & \\
Leisure & $91(51.7 \%)$ \\
Cultural \& spiritual needs & $15(8.5 \%)$ \\
Study tours & $15(8.5 \%)$ \\
Other & $54(31.3 \%)$ \\
Length of stay & $98(55.7 \%)$ \\
Day trip & $57(32.4 \%)$ \\
1 to 6 nights & $21(11.9 \%)$ \\
7 nights or longer & \\
Travel party & $80(45.5 \%)$ \\
Family & $55(31.3 \%)$ \\
Friends & $21(11.9 \%)$ \\
Self & $20(11.4 \%)$ \\
Others &
\end{tabular}




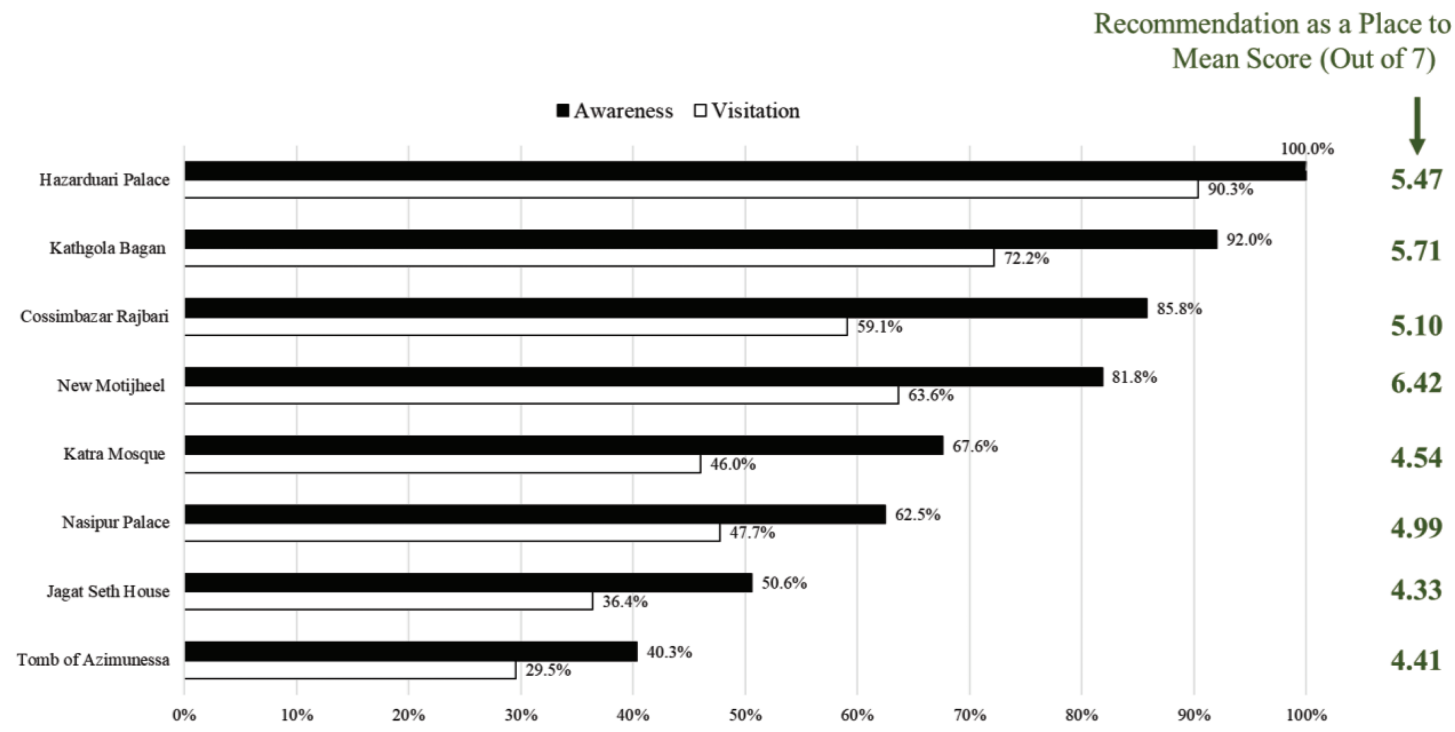

Figure 6. Awareness, visitation and recommendation of cultural sites.

aware of Hazarduari Palace and over $80 \%$ of tourists were aware of the other three sites listed above. The other four listed sites (Katra Mosque, Nasipur Palace, Jagat Seth House, Tomb of Azimunessa) had moderate awareness, ranging from $67.6 \%$ for Katra Mosque to $40.3 \%$ for Tomb of Azimunessa. These could be considered secondary in the minds of tourists. Visitation generally followed awareness in terms of ranking of cultural sites. The ratio of visitation to awareness can be considered a "conversion" rate. Hazarduari Palace had the highest visitation- $90.3 \%$ of tourists to Murshidabad visited this palace. The second highest visitation was for Kathgola Bagan at $72.2 \%$. This means $78.4 \%$ of those who were aware of this site visited the attraction. The other site with a relatively high conversion rate was New Motijheel where $77.8 \%$ of those who were aware of the site $(81.8 \%)$ visited the site $(63.6 \%)$. While visitation was relatively low for Tomb of Azimunessa (29.5\%), only $40.3 \%$ were aware of this site-a conversion rate of $73.2 \%$.

Tourists were also asked to give their recommendations on a 7-point Likert scale. New Motijheel had the highest recommendation score with an average of 6.42 out of 7. Kathgola Bagan (5.71 out of 7) and Hazarduari Palace (5.47 out of 7) were also well above the average.
When asked about problems with the cultural resources in Murshidabad, awareness was a problem with $68.2 \%$ reporting problems with activities availability and a further $27.8 \%$ reporting problems with the publicity of attractions. A small proportion of tourists highlighted problems with connectivity $(4.0 \%)$.

In terms of trip expenditure, when asked how much tourists approximately spent in a day, apart from basic facilities, $56.3 \%$ reported spending less than 500rs (US\$7.25) and the other 43.8\% reported spending between 500rs and 1,000rs (US\$7.2514.50). When asked if extra facilities are available, how much they would spend, $4.5 \%$ would spend less than 500rs (US\$7.25), 56.8\% would spend between 500rs and 1000rs (US\$7.25-14.50) and $38.7 \%$ would spend more than 1000 rs (US\$14.50) per day. This demonstrates that tourists are willing to spend more at the destination, if they are aware of these attractions.

\section{Local Community}

This section reveals the local community's perceptions of cultural tourism. The local community of Murshidabad strongly believes that cultural tourism can result in unexplored areas being developed. These residents perceive that cultural tourism can 
Unexplored area can be developed

Cultural tourism plays pivotal role in poverty alleviation in.

Cultural tourism acts as community development tool

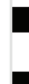

Government/private stakeholders' role in preserving.

Why tourists are not coming to these lesser known.

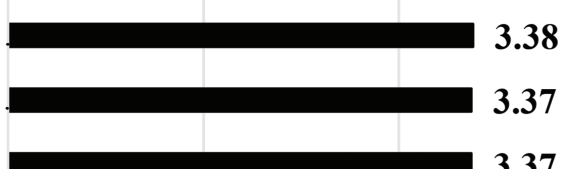

Tourism revenue is being utilized for maintenance and.

Loan facilities available to start up a new business

Media role in cultural tourism promotion

Local government assistance

Cultural activities to promote cultural tourism

NGO's role in cultural tourism promotion

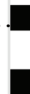

3.37

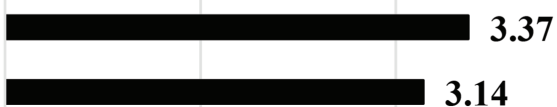

\subsection{3}

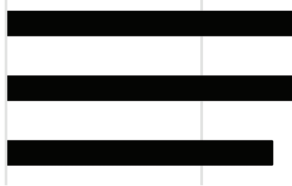

1

2

3

2.47

\subsection{3}

\subsection{6}

4

Figure 7. Perceived scope for cultural tourism development.

provide many benefits to the community such as poverty alleviation, be a community development tool, and preserve heritage resources. The local community is less likely to perceive that NGOs have a role in cultural tourism promotion and that cultural activities can promote cultural tourism (Fig. 7).

Cultural tourism encourages a variety of cultural activities by the local population.

Cultural tourism improves general entrepreneurial spirit and development amongst local people.

Local community is encouraged by local governing bodies to showcase their cultural resources

Local community is being consulted by local government and stakeholders in different stage of decision-making process.

Local community is attending cultural tourism related seminar, conference, workshops.
Figure 8 shows the local community's perceptions of cultural tourism. The top-rated perception is that "Cultural tourism encourages a variety of cultural activities by the local population," closely followed by "Cultural tourism improves general entrepreneurial spirit and development amongst local people." However, there are relatively low

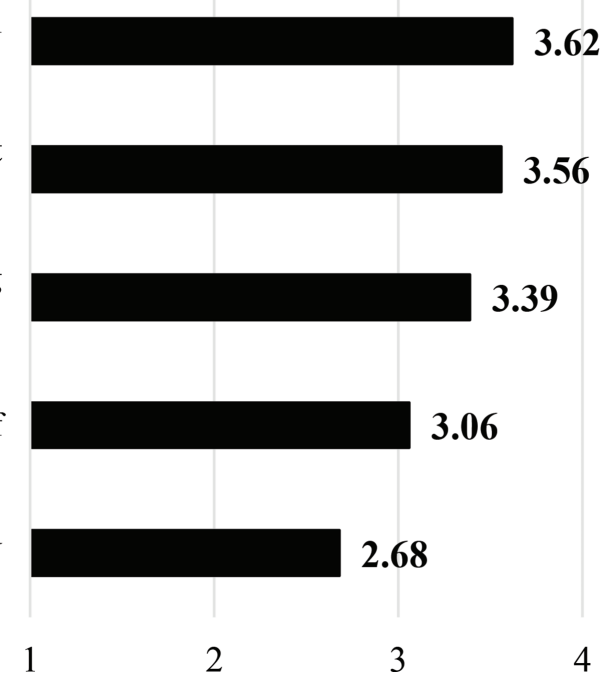

Figure 8. Perceptions of community participation in cultural tourism. 
mean scores for the local community participatory statement such as "Local community is attending cultural tourism related seminar, conference, workshops" and "Local community is being consulted by local government and stakeholders in a different stage of the decision-making process."

When asked to spontaneously nominate the current cultural resources under four different headings, Table 4 displays the results of the top five mentioned cultural resources under each category. In terms of sites for local handicrafts, Khagra-Kansa was the top mentioned place. Others mentioned in this category were Murshidabad silkLalbagh/Islampur, Beedi silpa-jangipur, Shola work-jiagunj, and Sandlewood etching-jiagunj/ lalabagh. Two forms of tangible culture had high mentions as a cultural tourist attraction. These were Bara Utsav and Baul Gaan. Apart from these two forms of culture, there was mediocre awareness of Pous mala and relatively low mentions of Jhumur and Monohara sweet.

In terms of cultural/heritage sites, residents mentioned Hazarduari Palace, Cossimbazar Rajbari, Katra Mosque, Kathgola Bagan, and New Motijheel. These top five had the highest awareness

Table 4

Top 5 Cultural Attraction (Percent Mentioned)

\begin{tabular}{ll}
\hline Places for local handicrafts & \\
Khagra-Kansa & $68.1 \%$ \\
Murshidabad silk-Lalbagh/islampur & $51.9 \%$ \\
Beedi silpa-jangipur & $47.6 \%$ \\
Shola work-jiagunj & $45.2 \%$ \\
Sandlewood etching-jiagunj/lalabagh & $45.2 \%$ \\
Cultural/heritage attractions & \\
Hazarduari Palace & $51.4 \%$ \\
Cossimbazar Rajbari & $45.7 \%$ \\
Katra Mosque & $41.9 \%$ \\
Kathgola Bagan & $41.9 \%$ \\
New Motijheel & $41.0 \%$ \\
Tangible cultural resources & \\
Bara Utsav & $85.7 \%$ \\
Baul Gaan & $70.5 \%$ \\
Pous mala & $48.1 \%$ \\
Jhumur & $28.1 \%$ \\
Monohara sweet & $26.2 \%$ \\
Lesser known attractions & \\
Karnasubarna & $57.6 \%$ \\
Nasipur Rajbari & $45.7 \%$ \\
Tomb of Azimunessa & $44.8 \%$ \\
Char Bangla Temple & $35.2 \%$ \\
Murshidabad District Museum & $33.3 \%$ \\
\hline
\end{tabular}

Table 5

Local Community Participation in Tourism \& Hospitality Services

Local community provide accommodation/home-

$4.8 \%$ stay facilitation

Local community provide transport facilities $\quad 97.6 \%$

Type of transport facilities

Car rental

$61.7 \%$

Auto

$34.4 \%$

Rickshaw

$3.8 \%$

among tourists (see above) although the order of awareness was slightly different. Nevertheless, Hazarduari Palace had the highest awareness among both cohorts. The lesser-known attractions were, in order of mentions, Karnasubarna, Nasipur Rajbari, Tomb of Azimunessa, Char Bangla Temple, and Murshidabad dist museum. As noted above, tourists also had relatively low awareness of the Tomb of Azimunessa.

Residents of Murshidabad did not believe that they can provide an adequate provision of lodging (less than 5\%), but there was a high perception that the local community can provide transportation. Almost all respondents believed the local community can be involved in transportation services $(97.6 \%)$ with car rentals being the most commonly suggested transportation to tourists. This was followed by autos and a few residents were offering rickshaws (Table 5).

The local community was asked to provide their opinions on how to further develop cultural tourism in Murshidabad. Four statements were provided. The recommendation with the highest mean score was to "Apply new approaches for tourism development and take new initiatives for tourist attractions." This was followed closely by two

Table 6

Ratings of Suggestions to further Develop Cultural Tourism: Mean Score Out of 5

Apply new approaches for tourism development

and take new initiatives for tourist attractions

Create awareness through different kinds of educa-

4.43

tional program among communities

Promote the existing resources with the help of government and stakeholders

Maintain and preserve the tourism resources for 3.90 cultural sustainability 
suggestions relating to marketing and public relations, namely "Create awareness through different kinds of educational programs among communities" and "Promote the existing resources with the help of government and stakeholders" (Table 6).

\section{Discussion and Conclusions}

The research assessed tourists' awareness, visitation, and likelihood to recommend cultural heritage resources in Murshidabad. Murshidabad has numerous historic and heritage cultural sites. Due to its history, the cultural sites are a mix from the Hindu, Nawabi, and British Colonial period. At present, some of them are maintained by the Archeological Survey of India. The River Padma in Jalangi is one of the major scenic attractions due to its strategic international location between India and Bangladesh as well as having an excellent panoramic view. Apart from the built heritage, Murshidabad attracts a significant number of tourists for various events and festivals. Among tourists, the awareness for the top four attractions is high, as is its satisfaction. Conversion (Visit/Awareness ratio) is also high ranging from $68 \%$ to $90 \%$. The top four attractions are Hazarduari Palace, Kathgola Bagan, Cossimbazar Rajbari, and New Motijheel.

The local community in Murshidabad has positive perceptions of cultural tourism. This is similar to previous studies. (Andereck et al., 2005; Türker \& Öztürk, 2013). They agree that cultural tourism can play a pivotal role in poverty alleviation in the local community, that cultural tourism acts as a community development tool and that tourism revenue can be used for the maintenance and preservation of local heritage (Ababneh, 2015; Henderson, 2011). In terms of the level of participation by the local community in cultural tourism development, residents perceive that they can participate in tourism in Murshidabad mostly through transportation, rather than offering accommodation services. Providing accommodation requires more resources and skills to offer a quality product to tourists. Providing accommodation requires the room to host guests and the business acumen and hospitality skills to meet tourists' standards. In contrast, providing transportation requires a vehicle and some communication skills. This can be more easily accomplished.

\section{Implications}

This study has both theoretical and practical implications. In terms of contribution to the literature, this study explores cultural tourism, particularly heritage tourism, from both a tourist's perspective and the local community's perspective. This enables a comparison between the demand for cultural tourist attractions and the supply of cultural tourist attractions. As such, we can identify any disconnect between cultural offerings and the types of experiences desired by tourists. The study also employs the marketing funnel approach to cultural tourism development. In terms of managerial implications, as noted above, the main issue relating to the cultural tourism attractions in Murshidabad is the lack of awareness and promotion of these sites. In the marketing funnel, this is the first phase. Tourists need to be aware of the attractions before they can visit them. Both tourists and the local community highlight that awareness of attractions in and around Murshidabad could be improved. As such, the recommendation to tourism stakeholders is to provide integrated marketing campaigns to promote different types of cultural attractions. These cultural attractions could be group as in Csapo's (2012) seven types of cultural tourism: Heritage Tourism; Cultural thematic routes; Cultural city tourism; Traditions; Events \& festival tourism; Religious tourism; and Creative culture. These categories of cultural attractions could be promoted on the destination marketing organization website. A mobile app could be created as now tourists are relying more and more on digital marketing and social media to discover tourist attractions (Cox et al., 2009; Mendes-Filho et al., 2018). Digital media can bring alive cultural tourist attractions by mixing visuals with sound and music. It is also recommended that managers of cultural tourist attractions be active on websites such as Tripadvisor as this is one of the main sources of information that tourists use to decide where and when to visit (Mate et al., 2019). Other recommendations include creating awareness through different kinds of educational programs among local communities. Local communities can be a source of information for tourists in recommending which cultural sites to visit. This can be augmented by the promotion of existing cultural resources with the help of different levels of government (Lehman et al., 2017). 
The regional government needs to play a supporting role so that genuine relationships between different levels of government, different government departments, the local community, and industry groups are created and fostered (de Brito et al., 2011). This will ensure the maintenance and preservation of tourism resources for cultural sustainability (Girard \& Nijkamp, 2009; Pechlaner et al., 2015). These recommendations are not only applicable to Murshidabad but other destinations throughout India and other developing countries that have an abundance of cultural resources.

Like any research, there are several limitations to this research that provide an opportunity for future research. Convenience sampling was undertaken. This can mean the sample is not necessarily representative of the target population. The profile of respondents shows that a varied demographic mix was surveyed; however, a stratified sampling technique matched to the Census might be more representative. This research used quantitative methods as it was deemed appropriate to answer the research objectives. Complementary qualitative interviews conducted among both tourists and the local community would enable policymakers to understand the reasons behind the awareness of some cultural attractions and not others and the triggers that prompt tourists, who are aware of some attractions but do not visit them, to be better understand their motives. In this way, policymakers and owners of the cultural resources can better target and market the attractions to tourists.

\section{References}

Ababneh, A. (2015). Managing heritage tourism in the Decapolis sites of Jordan: Planning opportunities and challenges. Tourism Culture \& Communication, 15(2), 141-156. https://doi.org/10.3727/109830415X14401707766006

Airey, D., \& Ruhanen, L. (2014). Tourism policy-making in Australia: A national and state perspective. Tourism Planning \& Development, 11(2), 149-162. https://doi. org/10.1080/21568316.2013.864991

Andereck, K. L., Valentine, K. M., Knopf, R. C., \& Vogt, C. A. (2005). Residents' perceptions of community tourism impacts. Annals of Tourism Research, 32(4), 1056-1076. http://dx.doi.org/10.1016/j.annals.2005.03.001

Ap, J. (1990). Residents' perceptions research on the social impacts of tourism. Annals of Tourism Research, 17(4),610-616.http://dx.doi.org/10.1016/0160-7383(90) 90032-M
Askjellerud, S. (2003). The tourist: A messenger of peace? Annals of Tourism Research, 30(3), 741-744.

Bettman, J. R., Luce, M. F., \& Payne, J. W. (1998). Constructive consumer choice processes. Journal of Consumer Research, 25(3), 187-217.

Camilleri, M. A. (2018). Integrated marketing communications. In M. A. Camilleri (Ed.), Travel marketing, tourism economics and the airline product (pp. 85-103). Springer Nature.

Canalejo, A. M. C., Tabales, J. N., López, J. M. C., \& Fuentes-García, F. J. (2015). Resident perceptions of community tourism in Cape Verde. Tourism, Culture \& Communication, 15(2), 103-119. https://doi.org/10.3727/ $109830415 \mathrm{X} 14401707765926$

Colicev, A., Kumar, A., \& O'Connor, P. (2019). Modeling the relationship between firm and user generated content and the stages of the marketing funnel. International Journal of Research in Marketing, 36(1), 100-116. https://doi. org/10.1016/j.ijresmar.2018.09.005

Cox, C., Burgess, S., Sellitto, C., \& Buultjens, J. (2009). The role of user-generated content in tourists' travel planning behavior. Journal of Hospitality Marketing \& Management, 18(8), 743-764.

Csapo, J. (2012). The role and importance of cultural tourism in modern tourism industry. In M. Kasimoglu \& H. Aydin (Eds.), Strategies for tourism industry - Micro and macro perspectives (pp. 201-232). InTech.

de Brito, P. M., Ferreira, A. M., \& Costa, C. (2011). Tourism and third sector organisations - Strangers or partners? Tourism Planning \& Development, 8(1), 87-100. https:// doi.org/10.1080/21568316.2011.554741

Deery, M., Jago, L., \& Fredline, L. (2012). Rethinking social impacts of tourism research: A new research agenda. Tourism Management, 33(1), 64-73. http://dx.doi.org/ 10.1016/j.tourman.2011.01.026

Doshi, A., Connally, L., Spiroff, M., Johnson, A., \& Mashour, G. A. (2017). Adapting the buying funnel model of consumer behavior to the design of an online health research recruitment tool. Journal of Clinical and Translational Science, 1(4), 240-245.

Dragouni, M., \& Fouseki, K. (2018). Drivers of community participation in heritage tourism planning: An empirical investigation. Journal of Heritage Tourism, 13(3), 237 256. https://doi.org/10.1080/1743873X.2017.1310214

Economist Intelligence Unit. (1993). The market for cultural tourism in Europe. Travel \& Tourism Analyst, 6, 30-46.

Fahmi, F. Z., McCann, P., \& Koster, S. (2017). Creative economy policy in developing countries: The case of Indonesia. Urban Studies, 54(6), 1367-1384. https://doi. org/10.1177/0042098015620529

Faulkner, B., \& Tideswell, C. (1997). A framework for monitoring community impacts of tourism. Journal of Sustainable Tourism, 5(1), 3-28.

Girard, L. F., \& Nijkamp, P. (2009). Cultural tourism and sustainable local development. Ashgate Publishing, Ltd.

Henderson, J. C. (2011). Built heritage conservation, urban development, and tourism: Singapore in the 21 st Century. 
Tourism, Culture \& Communication, 11(3), 137-147. https://doi.org/10.3727/109830412X13346876802112

International Council on Monuments and Sites. (1990). Charter for the protection and management of the archaeological heritage. http://wp.icahm.icomos.org/ wp-content/uploads/2017/01/1990-Lausanne-Charterfor-Protection-and-Management-of-ArchaeologicalHeritage.pdf

Jafari, J. (2001). The scientification of tourism. In V. L. Smith \& M. Brent (Eds.), Hosts and guests revisited: Tourism issues of the 21st century (pp. 28-41). Cognizant Communication Corporation.

Jansen, B. J., \& Schuster, S. (2011). Bidding on the buying funnel for sponsored search and keyword advertising. Journal of Electronic Commerce Research, 12(1), 1-18.

Jiang, Y., Cho, A., \& Adaval, R. (2009). The unique consequences of feeling lucky: Implications for consumer behavior. Journal of Consumer Psychology, 19(2), 171-184.

Jimura, T. (2011). The impact of World Heritage Site designation on local community - A case study of Ogimachi, Shirakawa-mura, Japan Tourism Management, 32, 288-296.

Jovicic, D. (2016). Cultural tourism in the context of relations between mass and alternative tourism. Current Issues in Tourism, 19(6), 605-612. https://doi.org/10.10 $80 / 13683500.2014 .932759$

Lankford, S. V., Chen, J. S., \& Chen, W. (1994). Tourism's impacts in the Penghu national scenic area, Taiwan. Tourism Management, 15(3), 222-227.

Lehman, K., Wickham, M., \& Reiser, D. (2017). Modelling the government/cultural tourism marketing interface. Tourism Planning \& Development, 14(4), 467-482. https://doi.org/10.1080/21568316.2016.1272483

Loulanski, T., \& Loulanski, V. (2011). The sustainable integration of cultural heritage and tourism: A meta-study. Journal of Sustainable Tourism, 19(7), 837-862. https:// doi.org/10.1080/09669582.2011.553286

Markusen, A., \& Gadwa, A. (2010). Arts and culture in urban or regional planning: A review and research agenda. Journal of Planning Education and Research, 29(3), 379-391. https://doi.org/10.1177/0739456x09354380

Mason, P., \& Cheyne, J. (2000). Residents' attitudes to proposed tourism development. Annals of Tourism Research, 27(2), 391-411.

Mate, M. J., Trupp, A., \& Pratt, S. (2019). Managing negative online accommodation reviews: evidence from the Cook Islands. Journal of Travel \& Tourism Marketing, 36(5), 627-644. https://doi.org/10.1080/10548408.2019. 1612823

McKercher, B., \& Du Cros, H. (2002). Cultural Tourism: The partnership between tourism and cultural heritage management. Haworth Press.

Mendes-Filho, L., Mills, A. M., Tan, F. B., \& Milne, S. (2018). Empowering the traveler: An examination of the impact of user-generated content on travel planning. Journal of Travel \& Tourism Marketing, 35(4), 425-436. https://doi.org/10.1080/10548408.2017.1358237
Mowforth, M., \& Munt, I. (2015). Tourism and sustainability: Development, globalisation and new tourism in the third world (4th ed.). Routledge.

Mubanga, K. H., \& Umar, B. B. (2016). "Tourism is for foreigners": Resident views about community participation in Zambia's tourist capital. Tourism, Culture \& Communication, 16(1-2), 75-89. https://doi.org/10.3727/10983 0416X14655571061791

Murphy, P. E. (1981). Community attitudes to tourism: A comparative analysis. International Journal of Tourism Management, 2(3), 189-195.

Noonan, D. S., \& Rizzo, I. (2017). Economics of cultural tourism: Issues and perspectives. Journal of Cultural Economics, 41(2), 95-107. https://doi.org/10.1007/ s10824-017-9300-6

Nunkoo, R., \& Ramkissoon, H. (2010). Community perceptions of tourism in small island states: A conceptual framework. Journal of Policy Research in Tourism, Leisure and Events, 2(1), 51-65. https://doi. org/10.1080/19407960903542318

Nyaupane, G. P., \& Andereck, K. L. (2014). Visitors to cultural heritage attractions: An actiVitY-BaseD integrateD tYPologY. Tourism, Culture \& Communication, 14(1), 17-26. https://doi.org/10.3727/109830414X14038917832824

Nyaupane, G. P., Teye, V., \& Paris, C. (2008). Innocents abroad: Attitude change toward hosts. Annals of Tourism Research, 35(3), 650-667.

Pechlaner, H., Bialk-Wolf, A., \& Zacher, D. (2015). The role of cultural activities in tourism development: An urban \& rural perspective. Tourism, Culture \& Communication, 15(1), 47-58. https://doi.org/10.3727/109830415X 14339495039450

Redondo-Carretero, M., Camarero-Izquierdo, C., GutiérrezArranz, A., \& Rodríguez-Pinto, J. (2017). Language tourism destinations: A case study of motivations, perceived value and tourists' expenditure. Journal of Cultural Economics, 41(2), 155-172. https://doi.org/10.1007/s10824017-9296-y

Richards, G. (2018). Cultural tourism: A review of recent research and trends. Journal of Hospitality and Tourism Management, 36, 12-21. https://doi.org/10.1016/j. jhtm.2018.03.005

Russo, A. P. (2002). The "vicious circle" of tourism development in heritage cities. Annals of Tourism Research, 29(1), 165-182.

Seyfi, S., Hall, C. M., \& Rasoolimanesh, S. M. (2020). Exploring memorable cultural tourism experiences. Journal of Heritage Tourism, 15(3), 341-357. https:// doi.org/10.1080/1743873X.2019.1639717

Sharma, B., \& Dyer, P. (2009). Residents' involvement in tourism and their perceptions of tourism impacts. Benchmarking: An International Journal, 16(3), 351-371. https://doi.org/10.1108/14635770910961371

Shin, Y. (2010). Residents' perceptions of the impact of cultural tourism on urban development: The case of Gwangju, Korea. Asia Pacific Journal of Tourism Research, 15(4), 405-416. https://doi.org/10.1080/1094 1665.2010 .520944 
Silberberg, T. (1995). Cultural tourism and business opportunities for museums and heritage sites. Tourism Management, 16(5), 361-365.

Simon, H. A. (1977). The organization of complex systems. In Models of discovery: And other topics in the methods of science (pp. 245-261). Springer Netherlands.

Sirakaya, E., \& Woodside, A. (2005). Building and testing theories of decision making by travellers. Tourism Management, 26(6), 815-832.

Söhnchen, F., \& Albers, S. (2010). Pipeline management for the acquisition of industrial projects. Industrial Marketing Management, 39(8), 1356-1364. https://doi. org/10.1016/j.indmarman.2010.04.001

Su, R., \& Cai, H. H. (2019). From cultural governance to cultural tourism-Towards an interpretation approach. Tourism, Culture \& Communication, 19(4), 291-302.

Suntikul, W., Pratt, S., I Kuan, W., Wong, C. I., Chan, C. C., Choi, W. L., \& Chong, O. F. (2016). Impacts of tourism on the quality of life of local residents in Hue, Vietnam. Anatolia, 27(4), 405-420. https://doi.org/10.1080/13032 917.2016.1138234

Tolkach, D., \& Pratt, S. (2021). Globalisation and cultural change in Pacific Island countries: The role of tourism. Tourism Geographies, 23(3), 371-396. https://doi.org/10. 1080/14616688.2019.1625071

Türker, A. N., \& Öztürk, A. S. (2013). Perceptions of residents towards the impacts of tourism in the Küre Mountains National Park, Turkey. International Journal of Business and Social Science, 4(2), 45-56.

Tylor, E. B. (1871). Primitive culture: Researches into the development of mythology, philosophy, religion, art, and custom (Vol. 2). John Murray.
United Nations World Tourism Organization. (1999). Tourism: 2020 vision. https://www.e-unwto.org/doi/pdf/10. 18111/9789284403394

United Nations World Tourism Organization. (2001). Cultural heritage and tourism development. https://www.eunwto.org/doi/pdf/10.18111/9789284404841

van Loon, R., \& Rouwendal, J. (2017). Travel purpose and expenditure patterns in city tourism: Evidence from the Amsterdam Metropolitan Area. Journal of Cultural Economics, 41(2), 109-127. https://doi.org/10.1007/s10824017-9293-1

Wang, Y. A., \& Pfister, R. E. (2008). Residents' attitudes toward tourism and perceived personal benefits in a rural community. Journal of Travel Research, 47(1), 84-93. https://doi.org/10.1177/0047287507312402

Wattanacharoensil, W., \& Schuckert, M. (2016). Reviewing Thailand's master plans and policies: Implications for creative tourism? Current Issues in Tourism, 19(10), 1045-1070. https://doi.org/10.1080/13683500.2014.88 2295

Woodside, A., \& Lysonski, S. (1989). A general model of traveller destination choice. Journal of Travel Research, 27(4), 8-14. https://doi.org/10.1177/0047287 58902700402

Young, R. A., Weiss, A. M., \& Stewart, D. W. (2006). Marketing champions: Practical strategies for improving marketing's power, influence, and business impact. John Wiley \& Sons.

Zieba, M. (2016). Tourism flows and the demand for regional and city theatres in Austria. Journal of Cultural Economics, 40(2), 191-221. https://doi.org/10.1007/ s10824-015-9250-9 